\title{
Power Plays and Capacity Constraints: The Selection of Defendants in World Trade Organization Disputes
}

\section{Citation}

Guzman, Andrew T., and Beth A. Simmons. 2005. Power plays and capacity constraints: the selection of defendants in world trade organization disputes. Journal of Legal Studies 34, no. 2: 557-598.

\section{Published Version}

http://dx.doi.org/10.1086/430767

\section{Permanent link}

http://nrs.harvard.edu/urn-3:HUL.InstRepos:3153319

\section{Terms of Use}

This article was downloaded from Harvard University's DASH repository, and is made available under the terms and conditions applicable to Other Posted Material, as set forth at http:// nrs.harvard.edu/urn-3:HUL.InstRepos:dash.current.terms-of-use\#LAA

\section{Share Your Story}

The Harvard community has made this article openly available.

Please share how this access benefits you. Submit a story.

\section{Accessibility}




\title{
Power Plays and Capacity Constraints: The Selection of Defendants in World Trade Organization Disputes
}

\author{
Andrew T. Guzman and Beth A. Simmons
}

\begin{abstract}
This paper examines the relationship between the wealth and power of states and their ability to participate fully within the World Trade Organization's system of dispute resolution. Two alternative hypotheses are considered. The power hypothesis predicts that politically weak countries will refrain from filing complaints against politically powerful states for fear of costly retaliation. The capacity hypothesis predicts that low-income states will tend to complain about behavior by high-income states because the latter offer a higher expected return. We test these two hypotheses and find considerable support for the capacity hypothesis and no support for the power hypothesis. We conclude that poor states behave differently than their rich counterparts because they lack the financial, human, and institutional capital to participate fully in the dispute resolution system.
\end{abstract}

\section{INTRODUCTION}

The 1995 birth of the World Trade Organization (WTO) was accompanied by a variety of procedural and substantive changes to the rules

ANDREW T. GUZMAn is Professor of Law at Boalt Hall School of Law, University of California at Berkeley. BeTH A. SIMMONS is Professor of Government at Harvard University. We are grateful to Chad Bown, Marc Busch, Stephen Choi, Anne Joseph, Geoff Manne, Petros Mavroidis, Niall Meagher, Joost Pauwelyn, Jay Smith, Steven Sugarman, participants at the Conference on International Dispute Resolution at the University of Chicago Law School, the Conference on International Law and International Relations at Vanderbilt Law School, the Conference on World Trade Organization Dispute Settlement and Developing Countries at the University of Wisconsin, the International Law West Conference 2005 held at Whitier Law School, the Latin American and Caribbean Law and Economics Association annual meetings and participants at faculty workshops at Boalt Hall, Chicago-Kent Law School, Georgetown Law School, Lewis and Clark Law School, the University of Illinois College of Law, and the University of Virginia Law School. Andrew Sternlight and Alexander Noonan provided invaluable research assistance.

[Journal of Legal Studies, vol. 34 (June 2005)]

(C) 2005 by The University of Chicago. All rights reserved. 0047-2530/2005/3402-0017\$01.50 
of the international trading system. ${ }^{1}$ The aspect of the WTO that has received the most attention is the new Dispute Settlement Understanding (DSU; World Trade Organization 1994). This unique mechanism for the settlement of disputes established a formal and mandatory set of procedures intended to make the resolution of disputes a matter of law rather than politics. Indeed, in the period immediately following the establishment of the WTO, the DSU was celebrated as a rule-of-law system that would replace the political and power-based system that had previously existed (Lacarte-Muro and Gappah 2000). ${ }^{2}$ It was not long, however, before skeptics emerged, suggesting that the system remained political and that the DSU was little more than a dressing up of the cold, harsh, power politics that had always existed in the trading system. Now, with 10 years of DSU practice behind us, we are just starting to understand how the system has actually worked, and we are able to investigate the extent to which it has replaced politics with law.

This paper seeks to contribute to our understanding of the role of the DSU and the role of power within that system. We investigate the litigation patterns of member states in an attempt not only to understand whether richer and more powerful countries enjoy an advantage at the DSU but also to shed light on the source of that advantage, if it exists.

An initial look at the data does not show any striking evidence that poor countries are second-class members when it comes to dispute resolution. Indeed, quite the contrary: even at first glance it is clear that developing countries are active participants in the system. ${ }^{3}$ They litigate both as complainants and defendants, win cases at the same rate as developed states, and settle cases at a rate comparable to developed states.

There are two main reasons, however, why a more nuanced study might reveal disadvantages facing poor countries at the DSU. First, they may face capacity constraints that limit the number of cases they are

1. New agreements on agriculture, health and safety, services, intellectual property, and more introduced a blizzard of new rules and obligations for members. The previous General Agreement on Tariffs and Trade (GATT) rules remained but were clarified or interpreted through several "understandings" that accompanied the final agreement. And of course the WTO itself was a new institution with new rules and procedures.

2. "This system works to the advantage of all [WTO] Members, but it especially gives security to the weaker Members. . . . In the WTO right perseveres over might" (LacarteMuro and Gappah 2000).

3. Distinguishing developed and developing countries may not be the best way to divide up the data, but it helps to get an initial sense of the data. In the empirical work that follows, we rely on gross domestic product (GDP) rather than development status. 
able to pursue. By capacity we mean the resources available to identify, analyze, pursue, and litigate a dispute. Under this capacity hypothesis, poor countries will file fewer cases because they lack the financial, human, and institutional resources to do so. Second, states may face political hurdles to bringing cases. Despite the DSU's attempt to take politics out of dispute resolution, ${ }^{4}$ politically weak countries may be deterred from filing a dispute for fear of retaliation by the would-be defendant. ${ }^{5}$ Like the capacity hypothesis, the power hypothesis predicts that countries will file fewer complaints if they are poor and politically weak than if they are rich and politically powerful.

The problem with testing these hypotheses directly is that we have no theoretically grounded baseline estimate of the number of cases a country is expected to initiate at any given level of income, capacity, or market power. This paper therefore adopts a more indirect approach. Rather than examine the absolute number of cases filed, we consider the kinds of states named as defendants. Studying the selection of defendants sheds light on the forces at work within the DSU. If the DSU is a rule-of-law system in which power and wealth are irrelevant, we would expect the income of the complainant to tell us nothing about the wealth of the defendant in a case. But if power structures dispute settlement processes, poorer countries should be expected to avoid litigation against more powerful defendants for fear of retaliation. Finally, if capacity constrains the use of dispute settlement procedures, weak states will be able to pursue only those cases with big net payoffs and will, therefore, go after the wealthiest defendants. By looking at the choice of defendant, we are able to design a crisp test for the sources of developing countries' disadvantages-if any-in protecting their interests through the WTO's dispute settlement mechanism. We find strong evidence that developing countries are constrained by their capacity to launch litigation and no evidence consistent with the power hypothesis.

The paper proceeds as follows. Section 2 provides a very brief sketch of the DSU, introduces some of the basic data on dispute resolution, and reviews the small empirical literature relevant to our inquiry. Section

4. See the DSU (World Trade Organization 1994, art. 3.10): "[R]equests for conciliation and the use of the dispute settlement procedures should not be intended or considered as contentious acts and . . . if a dispute arises, all Members will engage in these procedures in good faith in an effort to resolve the dispute. It is understood that complaints and counter-complaints in regard to distinct matters should not be linked."

5. There is empirical evidence that retaliation takes place. See Busch and Reinhardt (2003) and Reinhardt (2000). 
560 / THE JOURNAL OF LEGAL STUdiES / VOLUME 34 (2) / JUNE 2005

3 presents the theoretical arguments that inform our expectations about dispute initiation. Section 4 describes the regressions we run and the predictions made by the capacity and power hypotheses, while Section 5 presents and discusses our results. Section 6 discusses a variety of robustness checks that were carried out. Section 7 concludes.

\section{LAW, POLITICS, AND DISPUTE SETTLEMENT}

\subsection{The Working of the Dispute Settlement Understanding}

The DSU entered into force with the establishment of the WTO in 1995. It introduced a number of changes to the practices that existed under the pre-WTO General Agreement on Tariffs and Trade (GATT), and these changes are described in great detail in many other places (Cameron and Campbell 1998; Guzman and Simmons 2002). We, therefore, limit ourselves to a very brief overview sufficient for present purposes.

The key feature of the DSU is that it is an exclusive and mandatory system of dispute resolution. Any WTO member can complain about the conduct of any other member through a formalized process that includes consultations, a panel decision, an appeal, adoption, and implementation. A defendant can neither block the case nor generate endless delays, and the report of the panel or (if there is an appeal) the Appellate Body is formally adopted by the Dispute Settlement Body shortly after its circulation. ${ }^{6}$ The process is mandatory in the sense that once a complainant files a request for consultations, the case proceeds along a specified timeline to its conclusion and the defendant cannot prevent it from doing so.

In addition to its mandatory nature, the DSU is, by its own terms, exclusive. Article 23 of the DSU (World Trade Organization 1994) states explicitly that states shall make use of the DSU to address the nullification and impairment of WTO obligations and shall not make determinations about the WTO consistency of another state's conduct except through the DSU (see United States-Sections 301-310 of the Trade Act of 1974, WT/DS/152 [November 25, 1998]). Finally, the DSU seeks to

6. The report is adopted no later than 60 days after its circulation in the case of a panel report and no later than 30 days after circulation for appellate reports. Strictly speaking, a panel or appellate report is not automatically adopted because the dispute settlement body can decide by consensus not to adopt it. Because the dispute settlement body includes all WTO members, including both parties to the litigation, however, adoption is all but certain. 
Table 1. Dispute Settlement Understanding Participation by Income Level

\begin{tabular}{lcccrr}
\hline & $\begin{array}{c}\text { High } \\
\text { Income }\end{array}$ & $\begin{array}{c}\text { Upper } \\
\text { Middle } \\
\text { Income }\end{array}$ & $\begin{array}{c}\text { Lower } \\
\text { Middle } \\
\text { Income }\end{array}$ & $\begin{array}{c}\text { Low } \\
\text { Income }\end{array}$ & Total \\
\hline Cases as complainant & 217 & 66 & 44 & 25 & 352 \\
Cases as defendant & $(61.7)$ & $(18.8)$ & $(12.5)$ & $(7.1)$ & $(100)$ \\
\% of world trade, 1999 & 222 & 73 & 36 & 21 & 352 \\
& $(63.1)$ & $(20.7)$ & $(10.2)$ & $(6.0)$ & $(100)$ \\
& 78.7 & 6.8 & 12.1 & 2.3 & 100 \\
\hline
\end{tabular}

Note. Values in parentheses are percentages. Income categories are based on per capita incomes and correspond to the World Bank (2005a) income categories: low income, \$735 or less; lower middle income, \$736-\$2,935; upper middle income, $\$ 2,936-\$ 9,075$; and high income, $\$ 9,076$ or more.

a These data treat the European Community member states as a single country in calculating shares of world trade. The year 1999 is chosen because it falls in the middle of the data set.

remove politics from the dispute resolution process and discourage states from viewing a complaint as a hostile act. ${ }^{7}$

\subsection{Ten Years of Cases}

How successful has this system been at removing power relations from the settlement of trade disputes? Looking at the raw data from the dispute settlement system, it is surprisingly difficult to find obvious evidence of power or capacity constraints at work. Developing countries as a group are active participants in the DSU system. Of all the cases filed, 38 percent have featured a developing country complainant. ${ }^{8}$ Nor are developing countries defendants any more often than they are complainants. Table 1 shows the frequency with which countries are defendants or complainants, with countries categorized by income (see Appendix A for a list of countries by income level). The income categories are high income (HI), upper middle income (UMI), lower middle income (LMI), and low income (LI). ${ }^{9}$

Taking into account the share of world trade attributable to each income category does not change the basic point. Developing countries (all categories except the HI category) participate in the DSU system

7. See note 4 .

8. Our data on cases filed include all cases from the inception of the WTO through 2004. See Section 4.

9. The category "developed country" is identical to the high-income category, so 62 percent of cases feature a developed complainant and 38 percent feature a developing complainant. 
562 / THE JOURNAL OF LEGAL STUdiES / VOLUME 34 (2) / JUNE 2005

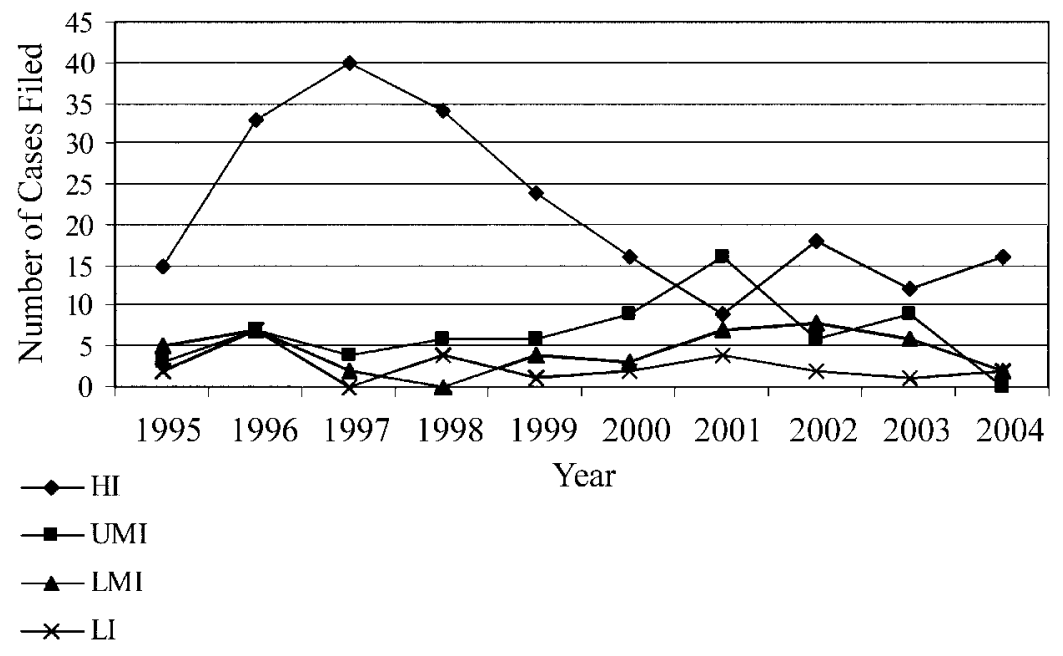

Figure 1. Cases filed by income category and year

more than we would expect on the basis of trade shares alone (Table 1, third row). Even within the set of developing countries, there is no systematic pattern of poorer countries being defendants more than they are complainants or of poorer states litigating less than suggested by their level of trade. ${ }^{10}$ Since 1997, filing rates of the wealthiest countries have tended to converge toward the rates of the middle-income groups (Figure 1).

At a minimum, these data make it clear that use of the DSU is not the exclusive domain of the wealthiest complainants. Developing countries turn to this mechanism to protect their interests as well. We cannot conclude from this, however, that the rule of law has erased the advantages of the wealthy. As shown below, the evidence suggests that poor countries have to pick their fights very carefully, and this is reflected in the type of defendants they pursue.

10. One striking fact that is not evident from Table A1 is that only one least developed country (Bangladesh), as defined by the United Nations, has participated in the DSU system as either a complainant or a defendant, and that country did so in only a single case. See India-Anti-dumping Measure on Batteries from Bangladesh, WT/DS306/1 (January 28, 2004). Like the WTO, this paper uses the United Nations (2005) list of least developed states. 


\subsection{Empirical Research}

Although empirical work on the WTO's dispute settlement system is at an early stage, there are two prior papers of particular relevance to this project. The best-known paper addressing the ability of poor countries to participate in the DSU is Horn, Mavroidis, and Nordström (1999; see also Holmes, Rollo, and Young 2003). In that paper, the authors investigate the initiation of WTO disputes and attempt to determine if there is an institutional bias against participation by developing countries.

Horn, Mavroidis, and Nordström (1999) assume that there exists a particular functional relationship between the diversity of a state's exports and the number of potential WTO cases it faces. They use this assumption to predict the number of disputes a state should face and compare this prediction with the actual number of cases filed by the country. Using data from the first 4 years of the DSU, they find that the number of disputes brought by most members falls within a 95 percent confidence interval around their estimated number. Two aspects of the study make it difficult to evaluate the reliability of their findings. First, for many countries the 95 percent confidence interval predicting the number of disputes includes zero. This means that the large number of WTO members who have never been complainants behave as predicted, but it is difficult to know if this reflects the fact that diversity of trade is really driving behavior or if some other factors discourage filing by these members. ${ }^{11}$ Second, some of the largest users of the system fall outside the relevant confidence intervals of Horn, Mavroidis, and Nordström (1999), with the United States, Canada, and India pursuing more complaints than predicted and Japan pursuing fewer. ${ }^{12}$

Horn, Mavroidis, and Nordström (1999) also investigate the possibility that capacity constraints limit the ability of some states to file cases. Using gross domestic product (GDP) per capita as a proxy for capacity, they find that states with low GDP per capita bring fewer cases than their model predicts but find no significant relationship between GDP per capita and the propensity to file a case. Finally, they produce some evidence that states with fewer WTO representatives tend to litigate

11. For example, both the power and capacity hypotheses would be consistent with a finding that many countries have never filed a complaint.

12. These results are found in one of their two specifications, which includes a threshold of $\$ 10$ million in trade value, below which the cost of pursuing a case will deter filing. In their alternative specification, without any minimum threshold, the United States, Canada, and the European Community pursue more cases than predicted. 
less, but this result is significant in only one of three specifications they use, and the regressions do not control for other possible factors. ${ }^{13}$

Horn, Mavroidis, and Nordström (1999) is an important contribution to our understanding of the DSU, especially because it was completed so early in the institution's history. Its main problem, and one the authors recognize, is that we simply do not know what causes states to file cases. Without good data on the set of potential cases, it is difficult to measure whether the number of cases a state has actually filed is larger or smaller than the number expected in a system without income bias.

The other paper close to our own is Bown (2003). Bown evaluates the factors that influence whether a state joins the dispute as a complainant or third party. Although the true focus of Bown's paper is on other questions, his results suggest that capacity and power influence a state's decision to become a third party but not its decision to become a complainant. In neither case, however, is he testing these hypotheses as directly as we attempt to do. ${ }^{14}$

\section{THEORIES OF POWER, CAPACITY, AND DISPUTE INITIATION}

We assume that states pursue litigation at the WTO when doing so offers benefits that outweigh the costs. We identify and isolate two main costs associated with WTO disputes: political costs (relevant to the power hypothesis) and resource costs (relevant to the capacity hypothesis). Political costs include any form of retaliation or sanction that a complainant might suffer in response to its filing a case. Resource costs include the financial, institutional, and human capital costs of a dispute. These

13. They look only to the number of cases filed, so there is no way to know, on the basis of their results, if the limited signs of capacity they find are really driven by capacity constraints or are a reflection of power imbalances. This is even true of their results for the number of WTO representatives because this figure is strongly correlated with GDP and GDP per capita. See Bown (2003).

14. Busch and Reinhardt (2003) present evidence that rich complainants are more likely to extract concessions from defendants than are poor complainants but that the complainant's income has no impact on the likelihood of winning before a panel. They interpret this as evidence that poor complainants are hampered by a lack of capacity, but only in prelitigation negotiation. In contrast to Bown (2003), Busch and Reinhardt further claim that a lack of market power with which to threaten a withdrawal of concessions does not appear to play a role. 
costs are more easily borne if the state has greater capacity. Thus, a state files a case at the WTO if and only if

$$
K-P-C>0
$$

where $K$ represents the expected gains from filing at the WTO, $P$ represents the political costs of filing, and $C$ represents the resource costs of a dispute.

In an attempt to get a better sense of the effect of income on DSU use, we look at the mix of complaints filed rather than their absolute number. If income affects the behavior of complainants, we hypothesize that it will also affect the defendants they select when filing a complaint.

The expected benefits, $K$, from a case consist primarily of improved access to a country's market. ${ }^{15}$ Most typically, a complaint will demand liberalization of a defendant's market ${ }^{16}$ or the termination of measures that harm the complainant's producers in some other way. ${ }^{17}$ We expect the size of these benefits to depend in significant part on the market size of the defendant because, after controlling for existing trade flows, liberalizing a larger market offers a larger opportunity to domestic exporters. Liberalization of the Canadian market, for example, is likely to offer smaller benefits to, say, the European Community (EC) than does liberalization of the American market. Characteristics of the complainant affect the cost side of the litigation decision, and we now turn to consider these.

15. In some cases a complainant will seek some goal other than the opening of a market. For example, some cases address an allegation of a WTO-inconsistent subsidy (for example, see Australia-Subsidies Provided to Producers and Exporters of Automotive Leather, WT/DS/126 [May 8, 1998]). In such cases, one would still expect capacityconstrained complainants to select high-GDP defendants, all else equal, because violative conduct by potential defendants with large economies is more likely to have a large impact on the complainant's economy. Thus, an illegal subsidy by a large country is likely to have a larger impact on sales by local producers than would a similar subsidy by a small country. Similarly, disputes over compliance with the Trade-Related Aspects of Intellectual Property Rights (TRIPS) agreement (see Brazil-Measures Affecting Patent Protection, WT/DS/199 [June 8,2000$]$ ]) are of greater importance to a complainant if the defendant has a large market.

16. For example, a complainant may complain of illegal discrimination in the defendant's market, as was done in Japan-Taxes on Alcoholic Beverages, WT/DS/8 (June 29, 1995).

17. One example of this sort of case would be a complaint alleging an illegal subsidy, such as that in United States-Tax Treatment for Foreign Sales Corporations (FSC), WT/ DS/108 (November 28, 1997). Although it is rare, the complainant may also be protesting measures that harm its consumers. See Japan-Measures Affecting the Purchase of Telecommunications Equipment, WT/DS/15 (August 24, 1995). 
566 / THE JOURNAL OF LEGAL STUdies / VOLUME 34 (2) / JUNE 2005

\subsection{Complainant's Capacity}

Consider first the role of a complainant's capacity, by which we mean the institutional, financial, and human resources available to pursue a case. ${ }^{18}$ States that commit more people to trade issues and have more qualified individuals working in the area, more mature and sophisticated institutions to handle trade matters, and more financial resources to address trade disputes are higher capacity states.

We model capacity costs $(C)$ as a function of the resource costs of monitoring, investigation, negotiating, filing, and litigating a case $(Q)$ and the resources available to the country $(R)$, such that $C=Q / R$. For simplicity, we assume $Q$ to be constant across all disputes. The value of $R$ varies depending on the capacity of the complainant.

The result is that a country with less capacity faces a higher opportunity cost when it files a complaint (Sevilla 1998). When well-trained and capable officials investigate and pursue a complaint, they are taken away from other work. The more limited the capacity of the government, the more difficult it is to find appropriate people to staff a case and to make up for the work that these people would otherwise be doing. A country with larger capacity will have more people with better training dedicated to the pursuit of trade cases or to other closely related responsibilities. Such a country is also likely to have a much larger number of people available to do the work that would otherwise have been done by the individuals charged with pursuing a case. The financial costs are similarly easier to bear for a country with greater resources. However difficult it is for a developed country to pay the financial costs of a case, it is surely much harder for a poor, developing country to do so. ${ }^{19}$

The shortage of resources may represent a relevant constraint at every stage. A state with limited resources will invest less in monitoring trading rules abroad and investigating alleged violations by trading partners.

The growing complexity of trade law under the WTO makes these

18. Some states may have sufficient capacity to pursue every case for which the benefits outweigh the costs. For our purposes, we need only assume that for many states this is not the case. That is, we assume that a large number of states face a capacity constraint that prevents them from pursuing as many cases as they otherwise would. This capacity constraint may exist for any reason, including limited financial resources, human capital, institutional capital (for example, no effective mechanism for private parties to bring a complaint forward), and so on.

19. The cost differences may be even greater because developing countries may need to hire private counsel-generating a direct increase in costs-whereas a developed country may be able to rely on in-house government lawyers. 
capacity deficits all the more constraining. The WTO agreements now include not only the GATT but also an array of additional agreements covering a wide range of issues and legal requirements, including new areas such as services and intellectual property (Michalopoulos 1999). ${ }^{20}$ Furthermore, the jurisprudence of the WTO grows with each passing year, making it necessary to read numerous book-length panel and Appellate Body decisions in order to properly understand the legal context. All of this complexity is compounded by the inevitable layer of procedure that goes with a formal system of dispute resolution. ${ }^{21}$

All else equal, then, a country with limited capacity faces larger opportunity costs when it brings a case. Bearing these higher opportunity costs requires larger expected payoffs. We would expect states with a more limited capacity to focus their efforts on targets that offer the greatest potential to increase their exports. At any given level of trade, the demand for a product is more likely to be nearing saturation in a smaller market than in a larger market. Hence our expectation: capacityconstrained states are likely to pursue states with large markets, including the United States and the EC. Developing countries are forced to give up, this theory suggests, cases that involve smaller tangible payoffs. Unlike their wealthier counterparts, poorer countries will be unable to pursue cases that offer modest gains, long-term precedential value, ${ }^{22}$ or a "get tough" reputation in trade conflicts.

With different assumptions, of course, one can generate a capacitybased theory under which developing countries avoid large markets. One way to generate such a result is to assume that resource costs, $Q$, increase with the GDP of the defendant. In that case, low-capacity states may have a reason to avoid complaints targeting $\mathrm{HI}$ defendants. Although a model along these lines can be generated, we do not expect it to be borne out in the evidence. For capacity-constrained states to avoid HI defendants, the costs of litigation must increase with the wealth of the defendant faster than the expected benefits of access to a larger market. Furthermore, litigation carries with it certain fixed costs (for example,

20. "[J] ust to follow the topics of the various WTO bodies and attend their meetings requires a staff of at least 4-5 people, and the average is increasing . . . . [A] very large number of developing countries did not meet [this standard]" (Michalopoulos 1999).

21. Concerns over capacity issues have been raised by a number of other commentators (Michalopoulos 1999; Horn, Mavroidis, and Nordström 1999; Bown 2003).

22. Strictly speaking, WTO decisions do not have precedential value, but as a matter of practice later cases look to earlier cases for guidance in much the same way they would if those cases represented binding precedent. 
568 / THE JOURNAL OF LEGAL STUdiES / VOLUME 34 (2) / JUNE 2005

Table 2. Infrequent Filers: Countries That Have Filed a Single Case

\begin{tabular}{ll}
\hline Complainant & \multicolumn{1}{c}{ Defendant } \\
\hline Antigua and Barbuda & United States \\
Bangladesh & India \\
China & United States \\
Czech Republic & Hungary \\
Hong Kong & Turkey \\
Malaysia & United States \\
Nicaragua & Mexico \\
Norway & United States \\
Singapore & Malaysia \\
Sri Lanka & Brazil \\
Uruguay & European Community \\
Venezuela & United States \\
\hline
\end{tabular}

identifying a violation, participating in initial negotiations, crafting the basic arguments of the case). Filing against one wealthy defendant rather than, say, two less wealthy defendants avoids the need to bear these fixed costs twice. Low-capacity states, therefore, will be deterred from pursuing wealthy defendants only if the additional costs of those cases are sufficiently large to overcome the advantage of having only one set of fixed costs. In addition to our intuition that capacity is unlikely to work in this way, our empirical results are consistent with the capacity hypothesis presented in the body of the paper and inconsistent with this alternative theory.

There is some support for the capacity hypothesis in the raw data, as shown in Table 2. Of the countries that have complained only once at the WTO-and are therefore the most likely to face capacity issuesall but two brought their case against the United States, the EC, or a close neighbor of the complainant. ${ }^{23}$ This is consistent with our capacity model, which predicts that states bringing very few cases (that is, the most capacity constrained among those that have participated as complainants) will tend to pursue the largest targets and those with whom they already have large amounts of trade.

Finally, one might think that wealthy defendants are less promising

23. The cases that do not appear at first glance to be explained by an attempt to pursue the benefits of a large market or close economic ties are the complaints by Hong Kong and Sri Lanka, respectively. One might categorize the Sri Lanka complaint as being consistent with the capacity hypothesis inasmuch as Brazil represents one of the larger economies in the WTO, although it is admittedly not in the same league as the EC or United States. 
targets because they are more likely to win the case. That is, wealthy defendants are able to afford the best possible defense and may, as a result, win cases that a poorer defendant would lose. Once again, this is theoretically possible, but we are skeptical. ${ }^{24}$ The vast majority of all cases decided by a panel yield a victory for the complainant. Both developed and developing country complainants win approximately 90 percent of these cases, and developed and developing countries settle their cases at about the same rates. In any case, if wealthy defendants are unattractive because they are better litigators, we should see empirical results inconsistent with the predictions of the capacity hypothesis.

\subsection{Power}

An alternative determinant of filing patterns flows from the power defendants have to impose costs on complainants. The defendant may consider use of the DSU to be a hostile act and may retaliate through trade, foreign aid, or other areas of international relations. We hypothesize that the political costs of filing, $P$, are a function of the difference in political power between the complainant and the defendant, meaning that $P$ is a function of the relative power of the parties:

$$
P=P\left(p_{c}-p_{d}\right),
$$

where $p_{i}, i=\{c, d\}$, represents the political power of country $i$, measured in absolute terms.

The greater the power differential, the greater the ability of the more powerful state to impose costs on the less powerful state without concern for counterretaliation. The notion then is that less powerful states are reluctant to challenge more powerful states for fear of retaliation or retribution. The risk of retaliation exists in part because a defendant can react to a complaint in many ways that lie outside the WTO process. For example, foreign aid could be reduced, cooperation in other areas could be frustrated, and the general tenor of interstate relations could be harmed. Even within the trading system there could be retaliation. Legal measures could be put in place that harm the interests of the complaining party, resolution of other trade disagreements may be frus-

24. There is empirical evidence that the complainant's income has no effect on the probability that it will win a case that leads to a panel ruling (Busch and Reinhardt 2003). 
trated, or the defendant can retaliate with a suit of its own. ${ }^{25}$ For example, Reinhardt (2000) concludes that a complaint increases the probability of a subsequent case being filed by the defendant against the complainant by up to 55 times. Whatever the form of the retaliation, we expect it to be most pronounced when the defendant is more powerful than the complainant. ${ }^{26}$

To illustrate the power hypothesis, imagine that the EC has put in place an illegal safeguard measure. Two WTO members are affected by this violation: the United States and Brazil. Removing the safeguard would generate benefits to both potential complainants. ${ }^{27}$ Although the United States may face some political cost if it files a complaint, the fact that it is politically powerful gives it a greater ability to resist retaliation or to threaten harm to the EC should the latter retaliate. Brazil, on the other hand, is politically weaker than the EC and could face more severe consequences if it files a complaint. All else equal, we would expect the United States to be more likely than Brazil to file a complaint.

Now imagine the same situation, but change the potential defendant from the EC to Argentina and assume for simplicity that Argentina is comparable to Brazil in terms of political power. The United States remains more powerful than Brazil, but does it face a dramatically lower political cost than Brazil if it files? What if the defendant were much weaker than Brazil—say, Belize. Is it still true that Brazil faces political costs of filing that are significantly higher than those of the United States?

If the political costs change linearly with the difference in political power, including when the complainant is more powerful than the defendant, there will be no obvious difference in the mix of cases filed based on the power of the complainant. More powerful states will have lower costs with respect to every potential defendant, causing them to file more cases. Because the more powerful state has a low cost of filing

25. An example of a retaliatory filing is Brazil's requests for consultation in CanadaMeasures Affecting the Export of Civilian Aircraft, WT/DS/46 (June 21, 1996), which complained about Canadian subsidies to its regional aircraft industry. These complaints followed a complaint by Canada, Brazil-Export Financing Programme for Aircraft, WT/ DS/70 and 71 (March 14, 1997), made 9 months earlier, alleging illegal subsidization of the Brazilian regional aircraft industry.

26. Hudec (2002, p. 81) points out a further problem for weak countries pursuing strong defendants. "According to conventional wisdom, it is a waste of time and money for developing countries to invoke the WTO's dispute settlement procedures against industrial countries. . . . [R]etaliation will harm the developing country imposing it far more than it will harm the industrial country it is supposed to punish."

27. For simplicity, we assume that the benefits are the same for both. 
relative to the less powerful state, it is more likely to file in every case, regardless of the identity of the potential defendant. So the more powerful state is more likely to file against Belize, just as it is more likely to file against the EC. We would, therefore, observe more cases filed by the powerful state, but the power hypothesis would not predict a different mix of cases without additional assumptions.

This point has important implications for the results of this paper. Although our results fail to support the power hypothesis, we cannot rule out the possibility that power plays an important role in determining the number of cases filed. It may be that a more powerful country, all else equal, files more cases than a less powerful one. To be consistent with our results, however, the impact of power on litigation must affect only the number of cases filed and not the selection of defendants. What is clear from our results is that there is no evidence to support the view that poor or weak countries are especially reluctant to file against rich or powerful countries for fear of the political consequences.

Our prior is that political power has a more pronounced effect when the complainant is weak relative to the defendant and has less impact when the complainant is at least as powerful as the defendant. We expect that states are reluctant to file against countries more powerful than themselves but enjoy only modest cost savings when they file against a less powerful country rather than one whose power is equal to their own. To capture this intuitively satisfying notion, we consider a model in which the impact of power differentials is asymmetric. Specifically, we model the political costs $P$ such that $P=1 / a^{(p c-p d)}$, where $P$ represents the political costs borne by the complainant when it files a request for consultation, $p c$ represents a measure of the political power of the complainant, and $p d$ represents the political power of the defendant. Figure 2 illustrates the relationship we envision between power and the political costs of filing.

The notion here is that differences in political power matter most when the complainant is weak relative to the defendant because that is when there is the greatest potential for costly retaliation. As the differences in political power shrink, the political costs of bringing a case fall, but do so at a decreasing rate as the difference in power shrinks and as the complainant's power grows larger than the defendant's.

The two competing hypotheses, then, make different predictions about the relationship between the power and income of defendants and complainants. These are summarized as follows: 


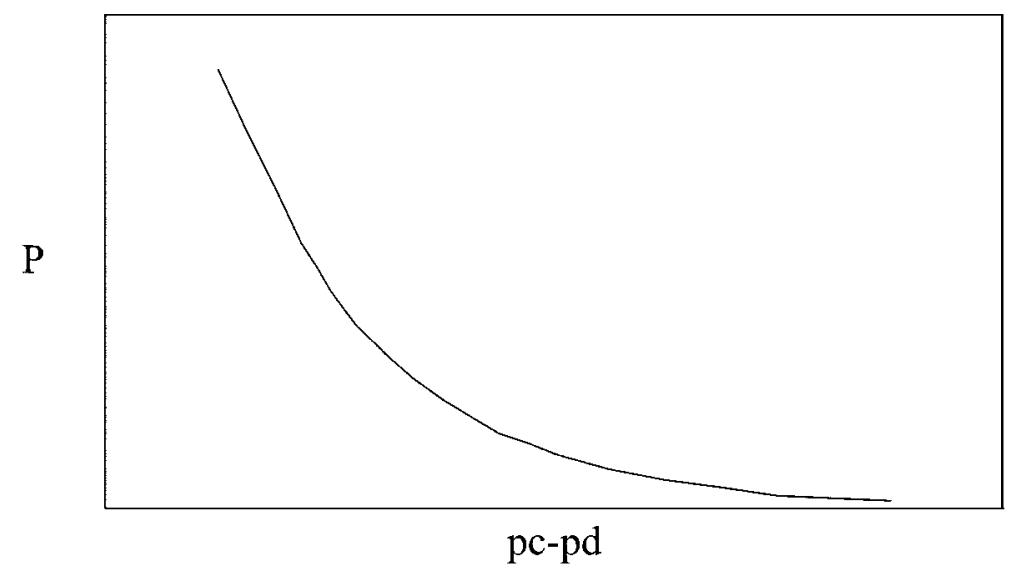

Figure 2. Political cost of filing

The Capacity Hypothesis. As a country's income falls, a larger percentage of its complaints will be directed at HI defendants.

The Power Hypothesis. As a country's political power falls, a larger percentage of its complaints will be directed at states with little political power.

To illustrate the working of each hypothesis, imagine the behavior of a state that faces a list of potential defendants, as shown in Tables 3 and 4 . The columns list the cases that the state will file, depending on the income level of the potential complainant.

All else equal, the capacity hypothesis suggests that a capacityconstrained state will be able to pursue only a limited number of cases. The state must prioritize the list of potential defendants and will tend to pursue larger markets rather than smaller markets. Thus, a lowcapacity complainant may pursue only one case, and that case will be against a defendant with a large market. If the complainant had a slightly higher but still below-average level of capacity, it would pursue some additional cases, prioritizing the defendants with the largest markets. If the complainant had above-average capacity levels, it would pursue still more states, again preferring to complain against large-market states. Finally, a high-capacity state might be able to file against all potential defendants. This behavior is illustrated in Table 3 .

The power hypothesis suggests that a politically weak state faces 
Table 3. Capacity Hypothesis Illustrated

\begin{tabular}{lcccc}
\hline \multirow{2}{*}{ Potential Defendant } & \multicolumn{1}{c}{ Lelow } & \multicolumn{2}{c}{ Above } \\
Average & \multicolumn{1}{c}{ High } \\
\hline United States & United States & United States & United States & United States \\
Japan & & Japan & Japan & Japan \\
Brazil & & Brazil & Brazil & Brazil \\
South Africa & & South Africa & South Africa \\
Turkey & & Turkey & Turkey \\
Egypt & & & Egypt \\
Costa Rica & & & Costa Rica \\
Pakistan & & & Pakistan \\
\hline
\end{tabular}

higher costs when it challenges a politically powerful state. So a lowpower complainant will be reluctant to file against any state with power greater than its own (or, more accurately, will require greater benefits as the power of the defendant increases). It will, therefore, tend to target the weakest of the potential defendants. If the complainant has slightly more power, it will target some larger number of defendants but will still select weaker rather than stronger states. If the complainant has still more power, the list of defendants grows and, finally, a high-power state might pursue every potential defendant. This behavior is illustrated in Table 4.

\section{EMPIRICAL TESTS}

We evaluate these claims about power and capacity using ordinary least squares regressions with robust standard errors. Because of the possibility that observations within country pairs are not independent, we calculate standard errors on the basis of country-pair clusters.

Our data set consists of all "requests for consultations" filed at the WTO since its inception in 1995 through the end of 2004. These data consist of 324 distinct requests for consultation, which include 352 complainant-defendant pairs because some complaints feature more than one complainant. As is done in most work on WTO dispute settlement, when a complaint features multiple complainants, we treat the data as if each complainant has filed a separate case (Busch and Reinhardt 2003; Horn, Mavroidis, and Nordström 1999). This is done because each complainant must decide independently whether it wishes to participate in the case and each complainant may settle with the defendant bilaterally. 
574 / THE JOURNAL OF LEGAL STUdies / VOLUME 34 (2) / JUNE 2005

Table 4. Power Hypothesis Illustrated

\begin{tabular}{|c|c|c|c|c|}
\hline Potential Defendant & Low & $\begin{array}{c}\text { Below } \\
\text { Average }\end{array}$ & $\begin{array}{c}\text { Above } \\
\text { Average }\end{array}$ & High \\
\hline United States & & & & United States \\
\hline Japan & & & & Japan \\
\hline Brazil & & & Brazil & Brazil \\
\hline South Africa & & & South Africa & South Africa \\
\hline Turkey & & Turkey & Turkey & Turkey \\
\hline Egypt & & Egypt & Egypt & Egypt \\
\hline Costa Rica & Costa Rica & Costa Rica & Costa Rica & Costa Rica \\
\hline Pakistan & Pakistan & Pakistan & Pakistan & Pakistan \\
\hline
\end{tabular}

\subsection{The Dependent Variable}

The main dependent variable of interest is the $\log$ of the defendant's GDP. This serves as a measure of both the political power and the market size of the defendant (see Appendix B for details of the data).

\subsection{Key Explanatory Variables: Capacity and Power}

Our primary empirical challenge is to develop reasonable proxies for power and capacity. The key variable in this regard is the log of the complainant's GDP. The size of the economy plausibly measures both the power and capacity of a complainant to defend its trade interests at the WTO, and our two hypotheses have opposing predictions. The power hypothesis views the complainant's GDP as an indicator of power and expects a positive coefficient: the larger the complainant, the more it is willing to take on powerful defendants; the smaller the complainant, the more it will be deterred from doing so for fear of retaliation. Gross domestic product also reflects aspects of a country's capacity to pursue disputes at the DSU. Larger economies have more human and technical resources with which to pursue a case. If capacity constraints predominate, we should see a significant negative coefficient for GDP as smaller states marshal their resources and pursue primarily large defendants. In this way, GDP provides a crisp test of the two hypotheses considered here.

The log of the complainant's GDP per capita is an alternative measure of both capacity and power. As a measure of power it suffers from the fact that high per capita GDP may be present in a small country with modest political power (for example, New Zealand), but we expect it nevertheless to be positively correlated with power. It is also a useful measure of capacity, in particular as a proxy for the human capital of 
trade officials. Ultimately we view GDP per capita as a less useful proxy for capacity or power than a country's total GDP. We expect both power and capacity to be correlated more closely with absolute measures of the state's resources and influence rather than its per capita wealth. Nevertheless, we use GDP per capita to test the robustness of our GDP results. A positive coefficient supports the power hypothesis, while a negative coefficient provides evidence in favor of the capacity hypothesis.

We include several other variables that serve as proxies for capacity and/or power. The first of these is the number of WTO representatives a state has in Geneva. The motivation for this variable is clear. States that have more WTO representatives are devoting more resources (human and financial) to the handling of WTO issues in Geneva and, one assumes, devoting greater resources within their own countries to these issues. The number of WTO representatives is a fairly direct indicator of the resources a country is able and willing to bring to bear on WTO cases. The variable also has the merit of having been used in previous work on the same subject (Bown 2003; Horn, Mavroidis, and Nordström 1999; Michalopoulos 1999).

Of course, a country's ability to pursue its trade interests is not limited to its staff in Geneva. Especially at the monitoring stage, countries with more extensive official economic contacts will be in a better position to assess trade policies that run counter to WTO rules and national interests. We capture this notion with data on the number of embassies a country maintains overseas. In part, this measures the ability of the government to field skilled diplomats (including economic officers) to gather information on which WTO complaints could plausibly be based. ${ }^{28}$ If the number of embassies reflects capacity in this way, the capacity hypothesis predicts that it should have a negative association with defendants' GDP. If, however, embassy networks are just another measure of a country's global interests and hence its power, the coefficient is expected to be positive.

Our next capacity measure more directly taps the financial capacity of the complainant government. A government pinched for resources is likely to be highly constrained in its programmatic efforts to defend its trade interests. Governments with limited financial resources are likely to have scant human and technical resources to devote to WTO issues.

28. Both the WTO representatives and the embassy variables are fixed throughout the period for each country. Although one would ideally like these proxies to adjust each year, we have no reason to think that there have been dramatic changes in either variable over the WTO's 10-year history. 
We use the log of the complainant's nonmilitary government expenditure, calculated annually, to test this kind of capacity constraint. Again, the capacity argument anticipates a negative coefficient.

Another measure of capacity looks to the quality of a country's bureaucracy. The bureaucratic quality measure is drawn from the International Country Risk Guide (PRS Services 2005; for a full discussion of the conceptualization and measurement of the bureaucratic quality measure, see Knack and Keefer 1995). This indicator measures the extent to which a country's bureaucracy is capable of carrying out a range of administrative tasks on a scale of 1 to 6 . The data are collected through surveys of individuals doing business internationally and reflect their perceptions of the quality of national bureaucracies. This measure has three weaknesses for our purposes. First, unlike the measure of Geneva staff, this measure is not specific to trade personnel. Second, it is less objective than the indicators of capacity that relate to Geneva staffs and embassy offices. Furthermore, unlike the three measures of capacity discussed above and like GDP per capita, bureaucratic quality is not affected by country size. Nonetheless, a subjective indicator of the general quality of a country's public bureaucracy may be a useful supplement to the more trade-oriented and objective measures discussed above.

Each of these capacity indicators is correlated to some degree, but they each tap into distinct aspects of the constraints developing countries may face. The number of WTO representatives is a direct indicator of staff directly available to pursue WTO issues. The number of embassies is a broader indicator of the informational and diplomatic constraints a government faces. Domestic expenditures reflect the financial resources at the government's disposal and perhaps most directly the notion of opportunity costs implicit in a tight budget constraint. Bureaucratic quality measures the functioning of government and perhaps the human capital of government officials. Because these are distinct but highly correlated, we chose to test these indicators sequentially rather than simultaneously.

Because none of these measures is a perfect measure of capacity to litigate, we include a behavioral indicator as well. Using a dummy variable, we control for a country's past participation in the DSU process. ${ }^{29}$ Participation itself indicates at least a minimal ability to take legal action or to defend against a claim. Moreover, participation-whether as a

29. To have participated in the past, it is sufficient to have been either a complainant or defendant in a request for consultations. 
Table 5. Prediction of the Hypotheses

\begin{tabular}{lcc}
\hline & \multicolumn{2}{c}{ Predicted Effect } \\
\cline { 2 - 3 } Complainant Variable & Power & Capacity \\
\hline Gross domestic product & + & - \\
Gross domestic product per capita & + & - \\
Number of World Trade Organization representatives & & - \\
Number of embassies & + & - \\
Nonmilitary expenditures & & - \\
Military expenditures & + & - \\
Bureaucratic quality & & - \\
Past participation & & \\
\hline
\end{tabular}

defendant or a complainant-contributes to capacity by developing experiential human and institutional capital. Those who have participated in DSU proceedings in the past are likely to have learned something from that experience, making it easier to pursue cases in the future. This "past participation" dummy takes on the value of one if the complainant has participated in DSU proceedings in the past as either a defendant or a complainant. The capacity argument would be supported by a negative correlation with the defendant's GDP as more experienced governments go after a broader range of defendants.

Some of these variables are plausible proxies for power in addition to capacity (GDP, for example). Nevertheless, we include in our regressions the log of the military expenditures of the complainant as a proxy for that state's power. Although military expenditures do not translate perfectly into political power in international relations, we certainly expect the two to be related. Table 5 summarizes the predictions each hypothesis makes with respect to these indicators.

\subsection{Controls}

In addition to the variables discussed above, we include a number of control variables. These control variables can be grouped into several clusters. The first cluster controls for the dyadic nature of the relationship between the complainant and defendant. There is empirical evidence, for example, suggesting that DSU participation is affected by the value of the complainant's imports from the defendant (Bown 2004), so we include the log of this value in our regressions. The relationship between imports and DSU activity is explained with a very particular sort of power argument. The notion is that at the end of the day, the complainant's primary tool to ensure compliance is the threat to impose 
trade sanctions (to "suspend concessions," in WTO parlance). The more the complainant imports from the defendant, the greater the potential for sanctions. ${ }^{30}$ Thus, the ability of the complainant to impose harm on the defendant through a withdrawal of concessions in the event of noncompliance with a panel or Appellate Body ruling influences the decision to pursue a case at the WTO (Bown 2003). Although the power hypothesis would predict a negative coefficient on this variable, ${ }^{31}$ we treat it as a control variable rather than a variable that yields information about the hypotheses that interest us. We believe the complainant's imports from the defendant are better viewed as a control because the size of the defendant is likely to affect this variable for reasons unrelated to either the capacity or power hypotheses. Simply put, country A may import a lot from country B because country B is large. This correlation between the defendant's size and the value of its exports will tend to produce a positive coefficient (and, indeed, that is what we observe in our regressions). This should not be taken to contradict the power hypothesis as it probably just reflects the relationship between the defendant's size and its exports.

Bown (2003) has also found that the complainant's exports affect dispute initiation. To address this concern, we include the complainant's exports to the defendant divided by the complainant's total exports as a control variable. The notion here is that a state is more likely to pursue a WTO complaint if the defendant is an important trading partner. If, for example, the majority of Canada's trade is with the United States, Canada is much more likely to pursue a case against the United States than against its other trading partners. ${ }^{32}$

We include a dummy that takes on the value of one if the defendant has filed against the complainant within the last year. This is done to

30. The sanctions permitted under the DSU are limited to an amount "equivalent to the level of the nullification or impairment" (World Trade Organization 1994, art. 22[4]). This might suggest that the threat of sanctions is maximized as long as the sanctions that can be imposed on the complainant's imports from the defendant are larger than the value of the nullification or impairment.

31. The power hypothesis predicts a negative coefficient because the ability to withdraw concessions will be more valuable when it can be done without fear of retaliation (that is, when the defendant is relatively weak). As the value of the complainant's imports from the defendant increases, a complainant has more incentive to seek a defendant against whom this can serve as a credible threat, which means weaker defendants.

32. An alternative specification would consider the dollar value of bilateral exports rather than the share of bilateral exports in total exports. Running the same regressions with this alternative specification did not affect the results as reported in our robustness discussion in Section 6. 
account for the possibility that some filings are retaliatory in nature, as suggested by Reinhardt (2000). If, in fact, some filings are retaliatory, the power hypothesis predicts that retaliation is less costly when the target is a relatively weak country than when it is a relatively strong one. Thus, the power hypothesis suggests that the retaliation variable should have a negative coefficient-retaliation should be more common when the defendant (against which the complainant is retaliating) is weak. That said, we do not place too much importance on this particular prediction because the threat of retaliation may affect the initial litigation decision of states. That is, a weak country may hesitate to complain against a powerful country because it fears a retaliatory complaint will be filed. If this pattern is common, it could deter enough filings by weak states to prevent the finding of a negative coefficient.

As a final dyadic indicator, we include a dummy that takes on the value of one if the parties to a dispute have a preferential trading agreement (PTA) in place to reflect the fact that states in PTAs may have alternative, non-WTO mechanisms for resolving disputes.

The second cluster of control variables attempts to take into consideration the nature of the case itself. For example, a truly dyadic dispute could differ systematically from those involving multiple complainants. ${ }^{33}$ Being one of a group of complainants may insulate the state from political pressure and may reduce the demands on its human and financial resources. For these reasons, we include a dummy variable that takes on the value of one when the complainant in the dyad is one of several complainants in the case before the WTO. ${ }^{34}$ Similarly, we include a dummy for what we label "bandwagon" cases-those that feature the same defendant and same issue as a previous case, but a different complainant. The idea here is that the second complainant to file on the same issue against the same defendant may enjoy some political cover as a result of being the second to file. ${ }^{35}$

33. Our data set includes seven requests for consultation in which there are multiple complainants, generating a total of 36 observations.

34. Thus, for example, in Hungary-Export Subsidies in Respect of Agricultural Products, WT/DS/35 (April 2, 1996), we include a separate observation for each of the complainants (Argentina, Australia, Canada, New Zealand, Thailand, United States), but the dummy variable for multiple complainants is equal to one in each observation.

35. For example, European Communities-Trade Description of Scallops, WT/DS/12 (July 25, 1995) and WT/DS/14 (July 31, 1995), were brought by Chile and Peru, respectively. The relevant dummy is set to one for the later complaint, brought by Peru. We include in the definition multiple cases filed on the same day and against the same defendant on the same issue. In those cases, all the dyads are labeled bandwagon cases and the relevant 
We include a dummy that takes on the value of one if the case in question is a refiled case, by which we mean there has been an earlier request for consultations between the same parties on the same issues (or perhaps a subset thereof) that was not resolved. ${ }^{36}$ We assign the value of one to the dummy in the refiled case and not in the original case because it is only in the latter case that one would expect changes in the consequences of a complaint. A refiling may put fewer pressures on a state's capacity constraint, and it may also feature a different political dynamic because it is, in some sense, a continuation of an earlier dispute.

Cases may also be influenced by the nature of the good or service under dispute. We include additional dummies to control for the particular WTO Agreement or agreements that have sparked the dispute. In our main regressions we include dummies for the Agriculture Agreement, the Anti-dumping Agreement, the General Agreement on Trade in Services (GATS), the GATT, the Sanitary and Phylosanitary Measures (SPS) Agreement, the Trade-Related Aspects of Intellectual Property Rights (TRIPS) Agreement, and the WTO Agreement. These agreements were chosen because the relative economic size of the parties seemed relevant to the existence of a dispute (for example, one might expect TRIPS-related disputes to frequently feature a wealthy complainant and a poor defendant), they accounted for a large number of disputes (for example, the GATT was at issue in 263 of our disputes and the Antidumping Agreement was at issue in 69), or because they were statistically significant in some of our robustness check regressions.

A third set of controls relates to qualities of the individual complainants and defendants that could plausibly affect the decision to initiate

dummy variable is assigned the value of one in each case. For instance, Japan-Taxes on Alcoholic Beverages, WT/DS/10 and WT/DS11, were brought by Canada and the United States, respectively, on July 17, 1995.

36. For example, Korea-Measures Concerning the Testing and Inspection of Agricultural Products, WT/DS/3 (April 6, 1995), was subsequently refilled as WT/DS/41 (May 31, 1996). The dummy variable for the earlier case (WT/DS/3) is set equal to zero, and the dummy for the later case is set equal to one. This dummy also takes on a value of one when the later case is a follow-up to the former and represents an effort to generate compliance. For example, European Communities-Regime for the Importation, Sale and Distribution of Bananas, WT/DS/158 (January 25, 1999), is a follow-up to the earlier Bananas cases (WT/DS/16, WT/DS/27), and the dummy is set to one for each of the dyads in the latter case. The precise definition of a refiled case is, of course, subject to judgments about what counts as the same issue. In an attempt to make this classification as objective as possible, we looked first to the subject matter of the case to see if it was the same as that in an earlier case, and we then looked to the request for consultations to determine if it reflected the same dispute as the earlier case. 
a dispute. We account for each country's general trade openness by including the log of the total trade of both the complainant and defendant divided by its GDP. There are no clear predictions regarding the coefficients on these variables from either the power or capacity hypotheses, but we include them as controls because the degree of openness in an economy is plausibly relevant to the frequency with which it files a complaint. And to ensure that our results are not driven by the two giants of the WTO-the United States and the EC-we include dummies for when each of these countries is the defendant and for when they litigate against one another.

In this third cluster, we also include a measure of the complainant's level of democracy. The notion here is that more democratic complainants may be more responsive to interest groups and may, therefore, pursue different defendants. The data we use are from the Polity IV Project data set (Marshall and Jaggers 2005) and tap the general openness of domestic political institutions. The data set includes six components: the extent to which a country has institutionalized procedures regarding the transfer of executive power, the extent to which governing executives are chosen through competitive elections, the extent of opportunities for nonelites to attain executive office, the extent of operational (de facto) constraints on the chief executive, the development of institutional structures for civil society's political expression, and the extent to which nonelites are able to access institutional structures for political expression. These characteristics pick up the main components of democratic governance. The scale runs from -10 (highly autocratic) to 10 (highly open and democratic).

Finally, one additional variable is included that does not fall into any of these clusters. We include a control for the presence of the Advisory Centre on WTO Law. The Centre, established October 5, 2001, provides legal advice, legal representation, and training to developing countries. We create a dummy variable equal to one if the Centre was in existence at the time of the dispute and the complaining state was eligible to use its resources. It is equal to zero otherwise. The Centre attempts to address the capacity problems facing poor states, and it is included because it may have affected the ability of developing states to pursue cases. Table 6 provides summary statistics for the key economic and explanatory variables used in the analysis. 
Table 6. Summary Statistics for Key Economic and Explanatory Variables

\begin{tabular}{|c|c|c|c|c|c|}
\hline & $\mathrm{N}$ & Mean & $\begin{array}{l}\text { Standard } \\
\text { Deviation }\end{array}$ & Minimum & Maximum \\
\hline Complainant gross domestic product ${ }^{\mathrm{a}}$ & 331 & $4.01 \mathrm{e}+12$ & $4.12 \mathrm{e}+12$ & $6.63 e+8$ & $1.03 e+13$ \\
\hline Complainant gross domestic product per capita ${ }^{a}$ & 331 & 17,831 & 12,718 & 381 & 46,553 \\
\hline \multicolumn{6}{|l|}{ Complainant number of World Trade } \\
\hline Organization representatives & 352 & 13.5 & 5.2 & 2 & 23 \\
\hline Complainant number of embassies & 352 & 99.5 & 37.9 & 0 & 158 \\
\hline \multicolumn{6}{|l|}{ Complainant nonmilitary general } \\
\hline government expenditures ${ }^{\mathrm{a}}$ & 285 & $6.31 \mathrm{e}+11$ & $6.46 \mathrm{e}+11$ & $6.46 e+8$ & $1.84 \mathrm{e}+12$ \\
\hline Bureaucratic quality & 327 & 3.39 & .87 & 1 & 4 \\
\hline Complainant military expenditures ${ }^{a}$ & 289 & $1.09 \mathrm{e}+11$ & $1.15 \mathrm{e}+11$ & $1.16 \mathrm{e}+8$ & $3.09 \mathrm{e}+11$ \\
\hline Complainant imports from defendant ${ }^{\mathrm{b}}$ & 332 & 42,486 & 64,881 & .22 & 251,598 \\
\hline Complainant exports to defendant ${ }^{\mathrm{b}}$ & 332 & 43,099 & 68,108 & 1.26 & 245,922 \\
\hline Complainant total exports ${ }^{\mathrm{b}}$ & 303 & 638,420 & 795,245 & 651 & $2,430,160$ \\
\hline Complainant total imports ${ }^{\mathrm{b}}$ & 303 & 686,533 & 781,180 & 1,643 & $2,321,950$ \\
\hline Defendant total imports ${ }^{\mathrm{b}}$ & 304 & 690,732 & 753,985 & 1,800 & $2,321,950$ \\
\hline Defendant total exports ${ }^{\mathrm{b}}$ & 304 & 604,218 & 747,562 & 645 & $2,430,160$ \\
\hline Past participation by complainant & 352 & .92 & .27 & 0 & 1 \\
\hline
\end{tabular}

${ }^{a}$ Constant 1995 U.S. dollars.

${ }^{\mathrm{b}}$ Millions of U.S. dollars. 


\section{RESULTS}

Table 7 presents ordinary least squares regression results testing the main hypotheses. The results offer strong support for the capacity hypothesis and virtually no support for the power hypothesis.

The coefficient on the GDP of the complainant is negative and highly significant (at the 1 percent level), which suggests that as a complainant's income falls, it tend to pursue wealthier defendants on average. This is precisely what the capacity hypothesis predicts-poor states will have limited resources, and these resources will be used strategically. Rich states are willing to file complaints against a broad range of defendants, whereas poor states are reluctant to file against other poor states. Controlling for a variety of relevant factors, we find that poor countries will use the DSU to bring cases against countries that offer larger rather than smaller markets for their products and, therefore, larger expected gains. The power hypothesis predicts just the opposite result, of course. So the coefficient on GDP is the first-and probably the most decisive-indicator that the results are driven by the complainants' capacity rather than the fear of retribution.

Our results are consistent with the alternative interpretation that increases in income cause states to pursue only poor defendants. One could imagine, for example, that poor states tend to file complaints against defendants without regard for the defendant's income, but rich states tend to file only against poor states. Although consistent with our results, we are unable to imagine a coherent theory under which poor states are prepared to file complaints against rich states but all else equal rich states are reluctant to do the same. Without a theoretical explanation for such behavior, it is reasonable to interpret our results as providing support for the capacity hypothesis.

In five of the six models presented, the complainant's GDP is omitted. Our various measures of power and capacity-GDP, number of WTO representatives, number of embassies, nonmilitary expenditures, military expenditures, bureaucratic quality, and GDP per capita tend to be correlated, as shown in Table 8. We use a variety of measures as a robustness check, and, to that end, we include them one at a time in our regressions. We have left GDP per capita in the reported regressions to control for a complainant's developmental level because this measure is likely to be relevant for reasons other than capacity or power.

In models 2-5 we include our other proxies for capacity. In the first three of these models, our capacity measures are strongly negative and 
Table 7. Determinants of Defendant Selection

\begin{tabular}{|c|c|c|c|c|c|c|}
\hline & Model 1 & Model 2 & Model 3 & Model 4 & Model 5 & Model 6 \\
\hline \multicolumn{7}{|l|}{ Explanatory variables: } \\
\hline Complainant gross domestic product & $-.424 \% *$ & & & & & \\
\hline Complainant gross domestic product per capita & & -.076 & $-.196 * *$ & -.069 & $-.182 * *$ & $-.109 *$ \\
\hline \multicolumn{7}{|l|}{ Complainant number of World Trade } \\
\hline Organization representatives & & $-.077^{* *}$ & & & & \\
\hline Complainant number of embassies & & & $-.011 * *$ & & & \\
\hline Complainant nonmilitary expenditures & & & & $-.348 * *$ & & \\
\hline Bureaucratic quality & & & & & -.137 & \\
\hline Complainant military expenditures & & & & & & $-.376 * \%$ \\
\hline Past participation by complainant & $-.293^{+}$ & $-.416 * *$ & $-.475 * *$ & $-.283^{+}$ & $-.464 * *$ & $-.324 *$ \\
\hline \multicolumn{7}{|l|}{ Dyadic control variables: } \\
\hline Complainant imports from defendant & $.632 * *$ & $.516 * *$ & $.512 * * *$ & $.605 * *$ & $.458 * *$ & $.640 * *$ \\
\hline Complainant expenditure to defendant over & & & & & & \\
\hline complainant total expenditure & -.490 & -.295 & -.258 & -.429 & -.375 & -.565 \\
\hline Retaliation & .096 & .136 & .081 & .144 & .107 & .097 \\
\hline Preferential trading agreement & $-.905 * *$ & $-.818 *$ & -.474 & $-.898 * *$ & -.526 & $-.895 * *$ \\
\hline \multicolumn{7}{|l|}{ Case control variables: } \\
\hline Multiple complainants & $.279 *$ & .208 & $.273^{+}$ & .121 & .244 & $.208^{+}$ \\
\hline Bandwagon & .057 & .062 & .120 & .129 & .112 & .146 \\
\hline Repeat filing & $-.355 *$ & $-.403 *$ & $-.305^{+}$ & $-.411 * *$ & $-.419 *$ & $-.409 * *$ \\
\hline Antidumping & -.223 & -.156 & -.234 & -.166 & -.254 & -.227 \\
\hline
\end{tabular}




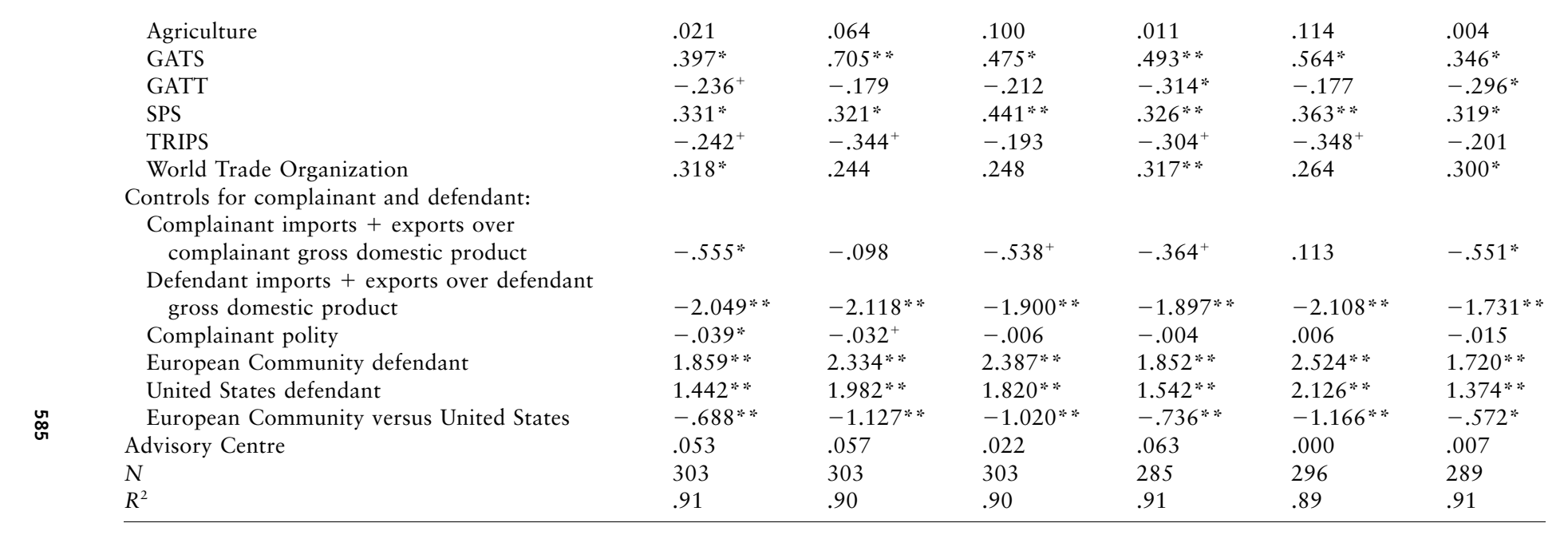

Note. The dependent variable is the log of the defendant's gross domestic product. GATS = General Agreement on Trade in Services; GATT = General Agreement on Tariffs and Trade; SPS = Sanitary and Phylosanitary Measures; TRIPS = Trade-Related Aspects of Intellectual Property Rights.

+ Statistically significant at the $10 \%$ level.

* Statistically significant at the 5\% level.

* Statistically significant at the $1 \%$ level. 
Table 8. Correlation Matrix for Capacity and Power Variables

\begin{tabular}{|c|c|c|c|c|c|c|c|}
\hline & $\begin{array}{c}\text { Gross } \\
\text { Domestic } \\
\text { Product }\end{array}$ & $\begin{array}{c}\text { Gross } \\
\text { Domestic } \\
\text { Product } \\
\text { per Capita }\end{array}$ & $\begin{array}{c}\text { Number of } \\
\text { World Trade } \\
\text { Organization } \\
\text { Representatives }\end{array}$ & $\begin{array}{l}\text { Number of } \\
\text { Embassies }\end{array}$ & $\begin{array}{l}\text { Nonmilitary } \\
\text { Expenditures }\end{array}$ & $\begin{array}{c}\text { Military } \\
\text { Expenditures }\end{array}$ & $\begin{array}{c}\text { Bureaucratic } \\
\text { Quality }\end{array}$ \\
\hline Gross domestic product & 1.00 & & & & & & \\
\hline $\begin{array}{l}\text { Gross domestic product } \\
\text { per capita }\end{array}$ & .75 & 1.00 & & & & & \\
\hline Number of World Trade & & & & & & & \\
\hline Organization representatives & .81 & .73 & 1.00 & & & & \\
\hline Number of embassies & .65 & .62 & .52 & 1.00 & & & \\
\hline Nonmilitary expenditures & .95 & .66 & .81 & .42 & 1.00 & & \\
\hline Military expenditures & .93 & .70 & .65 & .81 & .78 & 1.00 & \\
\hline Bureaucratic quality & .66 & .80 & .54 & .51 & .61 & .62 & 1.00 \\
\hline
\end{tabular}


significant, which indicates that countries with the capacity to do so extend their litigation to include smaller defendants. The number of WTO representatives, the number of embassies, and the level of nonmilitary government spending are all negative and significant (at the 1 percent level), as predicted by the capacity hypothesis. This constitutes reasonably consistent evidence in favor of the capacity hypothesis. Model 5, which includes bureaucratic quality as a capacity measure, yields a negative coefficient as predicted by the capacity hypothesis, but the coefficient is not significant. Notice that GDP per capita is negative and significant at the 1 percent level in this regression. Given the significant correlation between the bureaucratic quality measure and the GDP per capita measure, it is not surprising that only one of them is significant. When the same regression is run without GDP per capita, bureaucratic quality is negative and significant at the 1 percent level. As a result, although this regression does not provide strong evidence for the capacity hypothesis, we do not interpret it as being inconsistent with it either.

More support for the capacity hypothesis can be found in the strong negative relationship between past participation and the GDP of the target. The data indicate that states that have been party to one or more WTO cases and that, therefore, are likely to have greater familiarity with the system, tend to complain against less wealthy defendants. This suggests that lower capacity (in this case, less experienced) states select wealthier defendants. Once again, the power hypothesis would have led us to expect the opposite, at least to the extent that participation in WTO cases is a reasonable proxy for political power.

In model 6, we include military expenditures as a power variable. To the extent this variable is correlated with the wealth of the country (see Bown 2003), it could also be seen as a rough proxy for capacity. The relevant coefficient is negative and highly significant. This contradicts the power hypothesis and supports the capacity hypothesis.

It is interesting to note that the dummy for the Advisory Centre is not significant in any of our regressions. Coupled with the strong evidence of the capacity hypothesis, it is tempting to interpret this result as casting some doubt on the success of the Centre in relieving the burden on the capacity of poor states. This is not necessarily correct, however. If the Centre has increased the ability of poor states to litigate, it may have both caused some states to pursue defendants with lower GDPs and prompted some states that would otherwise have been unable to do so to file a complaint. That is, the Centre may bring resource-poor states into our data set by allowing them to pursue high-GDP defendants. This 
588 / THE JOURNAL OF LEGAL STUdies / VOLUME 34 (2) / JUNE 2005

would tend to increase the size of the coefficient. At the same time, the Centre may allow states that would file against a large defendant regardless to file also against smaller defendants with lower GDPs. This would tend to reduce the size of the coefficient. Both of these results would represent success for the Centre, and the net effect on our dummy variable's coefficient is ambiguous.

\section{ROBUSTNESS}

To check the robustness of our results, we ran a number of variations on the specifications presented in Table 7 . This section provides a summary of these robustness checks, some of which have already been mentioned. Our robustness checks are not reported because they all yield results consistent with the results presented.

First, we changed the combinations of explanatory variables. For example, we ran the regressions with the complainant's GDP per capita omitted, the net effect of which was to increase the magnitude of the other capacity measures. We also ran versions of models 2-5 with GDP included. These yielded highly significant negative coefficients on GDP, much like in model 1 , and coefficients on the other capacity proxies (number of WTO representatives, number of embassies, and nonmilitary spending) that were negative as in the reported regressions but not significant. We interpret this as evidence that the GDP proxy swamps these other proxies when they are combined.

We experimented with various combinations of country dummies included and excluded. Omitting the United States and EC dummies did not alter our basic results. We also included dummies for the five most frequent complainant states, India, Brazil, Canada, United States, and $\mathrm{EC}$, without affecting the results.

To guard against the possibility that the results are driven by some sort of change over time, we included a time trend as well as year dummies, without significant changes to our results. Neither the time trend nor any of the year dummies were significant in any of our regressions.

We included the log of the value of the complainant's exports to the defendant in place of the complainant's exports to the defendant divided by total complainant exports without affecting the results. This was done because it is plausible that the decision to litigate is triggered more by 
the absolute value of exports to a country than by the share of those exports to total exports. Again, our results were not changed.

The reported results include robust standard errors with standard errors clustered in country pairs. We ran the same regressions without clustering, and the results were similar to those reported.

To ensure that individual WTO agreements were not driving the results, we included all agreements at issue in more than 20 disputes. These additional dummies were almost never significant in our regressions, and all of the regressions that included these dummies generated results similar to those reported.

To guard against the possibility that collinearity among our trade variables are affecting the results, we ran the reported regressions with the openness variables (total trade over GDP) omitted. The reported results were unaffected by this change.

As a more general test of robustness and a protection against collinearity, we estimated a stripped-down version of the model, in which all controls were removed, with the exception of the bilateral trade data. The regression then included the variables identified in Table 7 as explanatory variables and the two trade variables referred to as dyadic control variables. Once again, the basic results reported in Table 7 were evident in this regression. ${ }^{37}$

One final question relates to the issue of selection bias. Clearly, countries have self-selected when they decide to complain against the trade policies of others; we are under no illusions that complainants in the WTO system are randomly selected. Is the problem of selection bias important, and is it likely to affect the claims we are making in this paper? Although we cannot rule out such an effect, we think it is unlikely to be problematic.

Notice that, to undermine our results, any selection effect must be very specific. It would have to lead to a set of filed cases in which lowcapacity states tend to pursue high-GDP defendants. So it would have to be a tendency for low-capacity states to settle their cases prior to the litigation phase at a disproportionate rate when the would-be defendant is a low-GDP state, and it would require that no similar effect is present with high-GDP states. Thus, for example, if low-capacity states simply file fewer cases, without regard for who the defendant would be, our

37. The one exception was the coefficient on the number of WTO representatives in model 2. In the stripped-down regression, this coefficient was significant only at the 10 percent level. 
590 / THE JOURNaL OF LEGAL STUdies / VOLUME 34 (2) / JUNE 2005

results remain reliable. Similarly, if poor countries are less likely to be defendants because the gains from winning a case against them are too small to justify the cost, all potential complainants would face a similar deterrent, and our results would not be affected. Another possibility is that high-GDP defendants are especially attractive because the leaders in the complainant state can somehow extract political gains by being perceived as strong and fearless in taking on a powerful adversary. Once again, one would expect such gains to be present for all potential complainants, in which case our results would not be affected. Furthermore, if for some reason leaders of poor states enjoy unusually large political rents from taking on powerful defendants, one would expect this to have an effect on the way in which cases settle or the way in which they are decided. Specifically, if relatively poor states seek out rich defendants for some political reason, one would expect the average quality of such cases to be lower than cases in general or than cases between poor states. It follows that in cases between poor complainants and rich defendants, the rate of settlement would be higher or the percentage of cases won by the complainant would be lower. Neither of these is present in the data. Ultimately, although we must cannot prove the absence of a selection effect that might influence our results, we are unable to imagine how such an effect could come about and think it unlikely to be driving our conclusions.

Because we observe the pattern of disputes conditional on the complainant initiating a case at the WTO, there are some claims that we are unable to make. In particular, we have not shown that a deficit in legal capacity explains the general reluctance of some countries to launch cases in the first place. It is possible, for example, that power plays a large role in determining which cases are brought. It may be that politically weak states simply bring fewer cases, reducing the total number of cases brought by weak states without altering the mix of defendants. To the extent that power is having this effect, our results indicate that the reluctance to litigate applies to all potential defendants and not simply the most powerful.

\section{IMPLICATIONS AND CONCLUSION}

Has the WTO succeeded in replacing politics with law in international trade disputes? A look at the number of cases initiated and eventually won by developing countries seems to suggest that they suffer no great 
disadvantage and that in fact they have equal access to trade justice under the enhanced dispute settlement mechanisms in place since 1995.

We have argued, however, that the number of cases launched is hardly proof that developing countries are equally able to defend their interests through legal forms of dispute settlement. In the absence of a clear sense of how many cases developing countries "ought to" have initiated, we really do not know if these filed cases represent equal access or not.

The evidence presented here indicates, however, that developing countries are using the DSU in a way that reflects their current incapacity to launch effective legal cases against potential trade law violators. Much of the difficulty, we have argued, is in the precomplaint phase, when a lack of human and technical resources reduces the ability to detect and develop a credible complaint. The capacity constraint is evident in the indirect evidence of a highly constrained choice of defendants. When the ability to effectively detect and prosecute violators is low, governments will pursue only the largest cases involving the most lucrative markets. Surprisingly, limitations on a government's capacity to litigate seem to be more important than the fear of political or economic retribution. Controlling for many alternative explanations, we find that poorer complainants have tended to focus on the big targets, a strategy that is consistent with a tight capacity constraint rather than a fear of retaliation.

The capacity hypothesis is supported by a range of indicators, none of which we would say is perfect, but which taken together present a fairly coherent picture. Whether measured by GDP, GDP per capita, specific WTO staff resources, general diplomatic resources, domestic financial resources, or past participation in WTO disputes, we find that having meager means results in highly targeted complaints aimed at the largest markets.

In some sense, our results are encouraging for developing countries. After all, these countries are going after the targets that matter most for their immediate trade interests. Some might even interpret our results as evidence that the weaker countries are in fact free riding on the broad trade law enforcement efforts of the wealthier governments. By this interpretation, the wealthiest governments may be supporting the public good of enforcing trade liberalization against a broad range of potential violators, even if the size of the market to which they seek access in a particular case is not especially large. Moreover, because accessing smaller countries is not worth the costs to any but the highest capacity 
complainants, our results suggest the former benefit as potential defendants by the capacity constraints of other developing countries.

These conclusions are tempting, but capacity constraints also imply the inability to achieve longer-term goals by making it difficult to pursue cases for their value as a precedent or their value in reputation building. Our findings suggest that these constraints relegate developing countries to tactical rather than strategic players in the international trade regime. Their necessary obsession with immediate net gains means they will likely be regime takers rather than regime makers for the foreseeable future.

If our results unveil new evidence of inequality between small players and major powers at the WTO, the good news is that the main problem does not appear to be the threat of coercive tactics by the powerful. If the problem is a deficit in the ability to initiate legal action, there are measures the international community can take to address this situation.

The Doha Round of WTO talks has been labeled the "Development Round." If this is to represent more than simply good marketing, WTO members might usefully turn their attention to matters of development with greater commitment than we have seen in the past. With respect to dispute resolution, this means giving developing countries the best possible access to the DSU, including assistance in the precomplaint phase. We view the WTO's Advisory Centre as a positive step and acknowledge that the ability to use private counsel in WTO proceedings, established in the EC Bananas case, is crucial (WT/DS/105 [October 29, 1999]). Increased funding and support for the Advisory Centre as well as continued efforts to train government officials from all countries in WTO law would further assist developing countries.

With respect to prelitigation capacity issues, solutions are more difficult to identify. Certainly the training of officials in relevant law and the greatest possible transparency in import measures are helpful but seem insufficient to give developing countries the maximum benefit of the DSU. Increased assistance (both financial and technical) to developing countries is needed. The WTO itself, although it has understandably been reluctant to act as a development organization, could provide expertise akin to the Advisory Centre, which is intended to assist countries in establishing appropriate monitoring schemes and evaluating potentially violative foreign practices. Developing countries themselves may be able to make some progress by pooling resources in the monitoring of trade practices, especially by countries with similar export portfolios.

Before jumping to conclusions about appropriate policy remedies, 
however, further research is needed to confirm and understand the extent of the capacity constraint examined here. We would welcome more diverse measures of a state's capacity to use the DSU, such as the size and budget of the trade ministry, and indicators of the quality of personnel (type and quality of training). Case studies on how highly constrained complainants actually select their defendants would provide interesting contextual evidence. Testing for the effect of alliances (security dependence) and aid or special trade preferences (developmental dependence) would be a good way to further explore the possibility for power to influence the selection of defendants. At this early stage in the research program, however, it would appear essential to take seriously the idea that limitations on the ability to pursue a case, rather than the fear of retaliation, are a major reason for the litigation patterns we see. 
594 / THE JOURNaL OF LEGAL STUdies / VOLUME 34 (2) / JUNE 2005

APPENDIX A: COUNTRY CLASSIFICATION

Table A1. World Trade Organization Member Countries, by Income Level

\begin{tabular}{|c|c|c|c|}
\hline High & Upper Middle & Lower Middle & Low \\
\hline Australia & Antigua and Barbuda & Brazil & Bangladesh \\
\hline Belgium & Argentina & China & India \\
\hline Canada & Chile & Columbia & Nicaragua \\
\hline Chinese Taipei & Costa Rica & Dominican Republic & Pakistan \\
\hline Denmark & Croatia & Ecuador & \\
\hline European Community & Czech Republic & Egypt & \\
\hline France & Hungary & Guatemala & \\
\hline Greece & Malaysia & Honduras & \\
\hline Hong Kong & Mexico & Indonesia $^{a}$ & \\
\hline Ireland & Panama & Peru & \\
\hline Japan & Poland & Philippines & \\
\hline Korea & Slovak Republic & Romania & \\
\hline Netherlands & Trinidad and Tobago & South Africa & \\
\hline New Zealand & Uruguay & Sri Lanka & \\
\hline Norway & Venezuela & Thailand & \\
\hline Portugal & & Turkey & \\
\hline \multicolumn{4}{|l|}{ Singapore } \\
\hline \multicolumn{4}{|l|}{ Sweden } \\
\hline \multicolumn{4}{|l|}{ Switzerland } \\
\hline \multicolumn{4}{|l|}{ United Kingdom } \\
\hline United States & & & \\
\hline
\end{tabular}

Note. Classifications are as of July 2004 and are from World Bank 2005b.

${ }^{a}$ Indonesia is classified as lower middle income from 1995-97 and lower income from 1998-2002.

APPENDIX B: DATA DESCRIPTIONS AND SOURCES

\section{B1. Dependent Variable: Log of Defendant's Gross Domestic Product}

The $\log$ of the defendant's 1995 GDP in constant 1995 U.S. dollars. The GDP data are from World Bank, WDI Online (http://devdata.worldbank.org/ dataonline).

\section{B2. Explanatory Variables}

Log of Complainant's Gross Domestic Product. The log of the complainant's 1995 GDP in constant 1995 U.S. dollars. The GDP data are from World Bank, WDI Online (http://devdata.worldbank.org/dataonline).

Log of Complainant's Gross Domestic Product per Capita. The log of the complainant's 1995 per capita GDP in constant 1995 U.S. dollars. Per capita GDP data are from World Bank, WDI Online (http://devdata.worldbank.org/dataonline). 
Number of Embassies Worldwide. The total number of embassies worldwide maintained by each country in mid-2000. Data are from Tagish, Embassies World Wide (http://www2.tagish.co.uk/Links/embassy1b.nsf/). Because no listings for the EC are included in this data set, we averaged the number of worldwide embassies of the EC's member states to obtain a reasonable estimate of the EC's worldwide diplomatic force.

Log of Nonmilitary Government Expenditure over Gross Domestic Product. Log of nonmilitary government expenditure/GDP was calculated by subtracting military expenditure (as a percentage of GDP) from total government expenditure (as a percentage of GDP), then multiplying by GDP, dividing by 100 , and taking the log. Data for government expenditure (as a percentage of GDP) and military expenditure (as a percentage of GDP) are from World Bank, WDI Online (http:// devdata.worldbank.org/dataonline).

Bureaucratic Quality. Data are spread on a scale of 1 to 6 and measure the extent to which a country's bureaucracy is capable of carrying out a range of administrative tasks. The bureaucratic quality measurements for a given country is fixed throughout the 10 -year period as we have no reason to believe that there have been dramatic changes in the variable over the WTO's history. For a full discussion of the conceptualization of the bureaucratic quality measure, see Knack and Keefer (1995). Data are from Knack and Keefer (1998).

Past Participation in the Dispute Settlement Understanding Process. If a country has previously participated in the DSU process as either a complainant or a defendant, then the dummy variable receives a value of one and a value of zero otherwise. Data are from World Trade Organization, Dispute Settlement: The Disputes (http://www.wto.org/english/tratop_e/dispu_e/dispu_status_e.htm).

Log of the Complainant's Military Expenditure. Complainants' military expenditure data are from World Bank, WDI Online (http://devdata.worldbank.org/ dataonline).

\section{B3. Control Variables}

\section{Dyadic Controls}

Imports to Complainant from Defendant. Complainant's imports from defendant, measured in current U.S. dollars. Data are from International Monetary Fund (2003). Data for bilateral trade with Taiwan are from Bureau of Foreign Trade (http://eweb.trade.gov.tw/eng2002/kmDoit.asp?CAT46\&CtNode $=643$ ).

Exports from Complainant to Defendant over Complainant's Total Exports. Complainant's exports to defendant divided by complainant's total exports, measured in current U.S. dollars. Data are from the 2003 IMF DOTS Database. Data for 
596 / THE JOURNAL OF LEGAL STUdies / VOLUME 34 (2) / JUNE 2005

bilateral trade with Taiwan are from Bureau of Foreign Trade (http:// eweb.trade.gov.tw/eng2002/kmDoit.asp?CAT46\&CtNode $=643$ ).

Retaliation. Dummy variable that takes on the value of one if the defendant has filed against the complainant within the last year.

Preferential Trading Agreement. Dummy variable that takes on the value of one if the countries in the case in question were involved, at the time of the dispute, in a PTA. To determine if a PTA was in force between the countries at the time of the dispute, we consulted WTO, Regional Trade Agreements Notified to the GATT/WTO and in Force (http://www.wto.org/english/tratop_e/region_e/ region_e.htm). Agreements identified as free-trade agreements or customs unions are considered PTAs for our purposes. Agreements identified as preferential arrangements were not counted as PTAs.

\section{Case Controls}

Multiple Complainants. Dummy variable that takes on the value of one when the complainant in the dispute is one of several complainants in the case before the WTO.

Bandwagon. Dummy variable that takes on the value of one if the case in question features the same defendant and same issue as a previous case but a different complainant.

Repeat Filing. Dummy variable that takes on the value of one if the case in question is a refiled case, by which we mean there has been an earlier request for consultations between the same parties on the same issues (or perhaps a subset thereof) that was not resolved. We assign the value of one to the dummy in the refiled case and not in the original case because it is only in the latter case that one would expect changes in the consequences of a complaint. Data are from World Trade Organization, Dispute Settlement: The Disputes (http:// www.wto.org/english/tratop_e/dispu_e/dispu_status_e.htm).

World Trade Organization Agreements. Series of dummy variables that take on the value of one when the relevant agreement is part of the dispute.

\section{Controls for Complainant and Defendant}

Log of Total Trade over Gross Domestic Product. The log of the sum of exports and imports of goods and services measured as a share of GDP. Data are from World Bank, WDI Online (http://devdata.worldbank.org/dataonline).

United States as Defendant. Dummy variable that takes on the value of one when the United States is the defendant in the case in question.

European Community as Defendant. Dummy variable that takes on the value of one when the EC is the defendant in the case in question. 
United States versus European Community. Dummy variable that takes on the value of one when the United States brings suit against the EC or vice versa.

Complainant's Level of Democracy. Data are from the Polity IV Project data set and tap the general openness of domestic political institutions. The scale runs from -10 (highly autocratic) to 10 (highly open and democratic). Data are from the Polity IV Project online database (Marshall and Jaggers 2005).

Advisory Centre. Dummy variable takes on the value of one if the WTO Advisory Centre was in existence at the time of the dispute in question and the complaining state was eligible to use the resources of the Centre. The Centre was established on October 5, 2001, and the conditions of eligibility can be found at Advisory Centre on WTO Law, Legal Advice (http://www.acwl.ch/e/ members/members_e.aspx).

\section{REFERENCES}

Bown, Chad P. 2003. Participation in WTO Dispute Settlement: Complainants, Interested Parties and Free Riders. Working paper. Brandeis University, Waltham, Mass.

- 2004. On the Economic Success of GATT/WTO Dispute Settlement. Review of Economics and Statistics 86:811-23.

Busch, Marc L., and Eric Reinhardt. 2003. Developing Countries and General Agreement on Tariffs and Trade/World Trade Organization Dispute Settlement. Journal of World Trade 37:719-35.

Cameron, James, and Karen Campbell. 1998. Dispute Resolution in the World Trade Organization. London: Cameron May.

Guzman, Andrew T., and Beth A. Simmons. 2002. To Settle or Empanel? An Empirical Analysis of Litigation and Settlement at the World Trade Organization. Journal of Legal Studies 31:S205-S235.

Holmes, Peter, Jim Rollo, and Alasdair R. Young. 2003. Emerging Trends in WTO Dispute Settlement: Back to the GATT? Working Paper No. 3133. World Bank, Washington, D.C.

Horn, Henrik, Petros Mavroidis, and Håkan Nordström. 1999. Is the Use of the WTO Dispute Settlement System Biased? Discussion Paper No. 2340. Centre for Economic Policy Research, London.

Hudec, Robert E. 2002. The Adequacy of WTO Dispute Settlement Remedies: A Developing Country Perspective. Pp. 81-91 in Development, Trade, and the WTO: A Handbook. Washington, D.C.: World Bank.

International Monetary Fund. 2003. Direction of Trade Statistics (DOTS). (CDROM). New York: International Monetary Fund.

Knack, Stephen, and Philip Keefer. 1995. Institutions and Economic Perfor- 
598 / THE JOURNAL OF LEGAL STUdiES / VOLUME 34 (2) / JUNE 2005

mance: Cross-Country Tests Using Alternative Institutional Measures. Economics and Politics 7:207-27.

- 1998. IRIS-3: File of International Country Risk Guide (ICRG) Data (computer file). 3d ed. College Park, Md.: IRIS (producer); East Syracuse, N.Y.: PRS Group (distributor).

Lacarte-Muro, Julio, and Petina Gappah. 2000. Developing Countries and the WTO Legal and Dispute Settlement System: A View from the Bench. Journal of International Economic Law 3:395-401.

Marshall, Monty G., and Keith Jaggers. 2005. Polity IV Project. http://www .cidcm.umd.edu/inscr/polity/\#data.

Michalopoulos, Constantine. 1999. Developing Countries in the WTO. World Economy 22:117-43.

PRS Services. 2005. International Country Risk Guide Researchers Dataset (1984-2004) (computer file). New York: Political Risk Services.

Reinhardt, Eric. 2000. Aggressive Multilateralism: The Determinants of GATT/ WTO Dispute Initiation, 1948-1998. Working paper. Emory University, Atlanta.

Sevilla, Christina R. 1998. Explaining Patterns of GATT/WTO Trade Complaints. Working Paper No. 98-01. Weatherhead Center for International Affairs, Cambridge, Mass.

Sullivan, Helena D. 2003. Regional Jet Trade Wars: Politics and Compliance in WTO Dispute Resolution. Minnesota Journal of Global Trade 12:71-108.

United Nations. 2005. List of Least Developed Countries. http://www.un.org/ special-rep/ohrlls/ldc/list.htm.

World Bank. 2005a. Country Classification. http://www.worldbank.org/data/countryclass/countryclass.html.

- 2005b. List of Economies. http://www.worldbank.org/data/databytopic/ CLASS.XLS.

World Trade Organization. 1994. Understanding on Rules and Procedures Governing the Settlement of Disputes (DSU). Legal Instruments 31:353-77. 